DOI 10.18551/rjoas.2020-02.14

\title{
ALTRUISTIC NORMATIVE INTERACTION AS A RENEWAL VARIABLE BEHAVIOR IN ORGANIZATION
}

\author{
Tuah Tuha Panca*, Doctoral Candidate \\ Study Program of Management Science, University of Sriwijaya, Paembang, Indonesia
}

Badia Perizade, Taufiq Marwa, Agustina Hanafi

Faculty of Economics, University of Sriwijaya, Palembang, Indonesia

*E-mail: pancatuah@gmail.com

\begin{abstract}
The relationship between interaction, normative force behavior in organizations and altruistic values are interpreted as altruistic normative interaction variables. This variable was built as a renewal in exploring between concepts. Based on social action theory, symbolic interaction theory, compliance theory, and value theory as well as support from previous research studies, the concept of altruistic normative interaction emerged. The concept of altruistic normative interaction is defined as Relationships that take place verbally in an interpersonal order that is carried out reciprocally and continuously in organizations with moral involvement in a positive value orientation that puts social interests and welfare of others first. This concept is expected to be a behavioral renewal variable in the organization and is expected to be a trigger in developing and improving individuals in the organization / company.
\end{abstract}

\section{KEY WORDS}

Interaction, normative structure, altruistic values.

According Weber in Rosenberg (2016) the world at this time was realized because of social action. Humans do something because it aims to achieve what they want, and then they choose an action. This explains that unconsciously, society is the end result of human interaction. As expressed by Weber, the best way to understand various groups is to respect the typical forms of action that characterize them, so that we can understand the reasons why the community act.

In the analysis of social action Weber introduced the concept of the meaning of an action. Weber said that individuals in society are creative actors and social reality is not a static tool rather than coercion of social facts. This explains that human action is not entirely determined by the norms, habits, values and so forth that are included in the concept of social facts. Although finally Weber acknowledged that in society there are social structures and social institutions.

Communication that takes place in a dialogical interpersonal face-to-face arrangement is called symbolic interaction. Now, symbolic interaction has become an interdisciplinary term of communication and sociology. Material objects are the same, namely humans, and human behavior (Ahmadi, 2008). Interaction is a term and claim of sociology; while the symbolic is the communication of communication or communication science. The main contribution of sociology to the development of social psychology which gave birth to the perspective of symbolic interaction. This development can be attributed to the flow of Chicago. The development of sociology in America has so far been preceded by the absorption of widespread sociological roots in Europe.

In Sociology, there are many theories and perspectives. Some use the perspectives of evolutionism, interactionism, functionalism, conflict theory, exchange, and there are also those who use divisions in view, namely social facts, social definitions, and social behavior. All approaches have different characteristics and objectives in order to analyze the community or analyze the organization (Ritzer \& Stepnisky, 2017). One of the most influential sociology theories is Symbolic Interaction which focuses on role behavior, interaction 
between individuals, as well as observable actions and communication. Through this approach, researchers can describe the development of its history and its benefits for individuals and society itself (Ahmadi, 2008)

Human resource research has explained a lot about the interactions and interrelationships between variables and research dimensions. Managerial effectiveness as an interaction between individuals and contextual factors (Hamlin, 2005; Miron, Erez, \& Naveh, 2004; Raelin \& Cooledge, 1995; Shao \& Webber, 2006). future leadership not only uses sophisticated technology, but the process of interaction must be considered (Bass \& Stogdill, 1990). Interaction needs to be done with various types of followers, including peers and superiors. Managers must move their leadership through interaction (Katz \& Kahn, 1978).

Real interaction has been specifically stated by George Herbert Mead (1863-1931) lecturer in philosophy at the University of Chicago. Mead stated that Communication that takes place in a dialogical interpersonal face-to-face arrangement is called symbolic interaction. Now, symbolic interaction has become an interdisciplinary term of communication and sociology. Material objects (materialum) are also the same, namely humans, and human behavior. This theory became popular under the name symbolic interaction theory

According Charon \& Interactionism (1979) interactions are formed symbolically including language, social objects, symbols, and various views. Interaction as a joint social action, individuals communicate with each other about what they do by orienting their activities to themselves. The interaction process must be more intensively carried out as a cross-functional function, carried out across departments, across managers, across companies and across national teams, so that managers become effective leaders in their interactions with their subordinates (Dumi, Ura, \& Çobo, 2012). Research Smith (2017) concludes through interaction that humans develop the concept of a larger social structure and also about themselves.

Blumer in Veeger (1985) further developed Mead's ideas by saying that there are five basic concepts in symbolic interactions; (1) self-concept, looking at humans is not merely an organism that moves under the influence of stimulus, both from outside and inside, but "organism that is aware of itself" (an organism having a self) (2) the concept of action (action), because human actions are formed in and through a process of interaction with oneself, the actions are completely different from the movements of creatures other than humans. (3) the concept of the object (object), looking at humans living in the middle of the object. (4) the concept of social interaction, interaction means that each participant moves himself mentally into another person's position. (5) the concept of joint action (meaning joint action), meaning that collective action born from the actions of each participant is then matched and adjusted to one another

The interaction does not only take place through gestures, but mainly through symbols that need to be understood and understood. In symbolic interactions, people interpret and interpret the movements of others and act according to that meaning. Closely related to the activities of human life with symbols because indeed one of human life is in a symbolic environment. By doing so, humans try to understand the intentions of actions carried out by others, so that interaction and communication is possible (Ahmadi, 2008).

Interaction in organizations has been widely studied and researched, as the theory put forward (Amite Etzioni, 1961) developed an innovative approach to organizational structure called compliance theory. Organizations are classified according to the type of power that directs the behavior of organizational members and the types of involvement and interactions that result. Normative through peer review, which is a non-dictatorial control, that is commonly used among higher ranking participants.

Organizations have three types of power; utilitarian, normative, and coercion. Compliance theory is an approach to organizational structure that integrates several ideas from classical and participatory management models. According to compliance theory, organizations can be classified by the type of power they use to direct the behavior of their members and the type of participant involvement. In most organizations, the type of power and involvement involved in three combinations is predicted: coercive-alienative, utilitarian- 
calculative, and normative-moral. Normative strengths, characterized as interesting work, identification with goals, and making contributions to society. the strength of management in this case lies in its ability to translate symbolic rewards, allocate self-esteem and prestige of symbols, manage rituals, and influence the distribution of acceptance and positive responses in organizations. Normative forces often create moral involvement for example, members of an organization committed to socially useful features of their organization. Moral involvement refers to a positive orientation with the involvement of strong identification with values that represent the organization. Many professional people work in normative organizations. All actions have a moral dimension but social order in some situations depends on people who obey the norms because they pay to (utilitarian) or because they fear not (coercion); they are not always obedient because they love rules or normative (Amitai Etzioni, 1975).

Research Sisaye (2005) states in the 1990s, team development and work groups have changed the traditional top-down hierarchical management control systems in many business organizations. Thus, three models of team-based control systems that compete in organizations have evolved based on the typology of Etzioni's power and control (1961, 1975). With related forms of obedience - moral under normative power, when alienative coercive power is used, and calculative in remunerative power.

According Lehman (2008) Etzioni continues to advocate the superior effectiveness of normative compliance does not make it an exclusive foundation. He suggested that all social units (not just organizations) that seek to treat members as the ultimate goal and not only as a cog in the social machine must adopt normative compliance. The advantages of normative compliance over utilitarian and coercive forms provide a bridge for Etzioni's socio-economic and communitarian theories. Furthermore, Clark \& Paivio (1991) explain Etzioni's Compliance Theory predicts and explains stability, effectiveness, and efficiency. The relationship between power usage and participant involvement, wherein the role of normative Power is involved. Participation, involvement, commitment and integration, which are described in the team as democratic decision-making processes, are considered as attributes related to normative-conceptual control systems. team democracy as a process factor that includes involvement in decision making, team interaction, listening and sharing feelings, communication, and satisfaction that enhance team performance (Coopman, 2001).

Research Prideaux (2018) states that Etzioni actually uses the same analogy to establish that social structure is more than just patterns of interaction, expectations and symbols. social structure also involves patterns of allocation of social assets, ownership of social units that are analytically classified as coercive, utilitarian, and normative.

In any organization, people are part of several power relations. When people go about their day, they do a lot of interactions, some where they are low-powered and others where they are powerful (Smith \& Hofmann, 2016). Organizational context not only impacts individual personal experiences but also changes the way people interact with each other (Schaerer et al., 2018). two important characteristics of organizations at the interpersonal level of interdependence and repeated interactions.

Interdependence; Organization is a collection of individuals with the aim of achieving collective goals (Baum, 2002). Thus, individuals in an organization are inherently interdependent in pursuing their high-level goals. Interdependence involves two or more actors who are emotionally, economically, and ecologically interdependent (Rusbult \& Van Lange, 2003). Individual results do not only depend on one's own strength but are also influenced by the actual or perceived strengths of other individuals. This effect is most likely to occur when social interaction is characterized by high levels of interdependence (Schaerer et al., 2018). Interdependence must be understood not only directly produced by a combination of certain behaviors but also in future behaviors and outcomes as a consequence of interactions (Kelley, 1984; Kelley et al., 2003).

Repeated interactions; interactions between individuals in the organization also occur repeatedly in a longer period of time. This is different from psychological strength research which mainly relies on disposable interactions between strangers (Flynn et al., 2011). Interaction and relationships are dynamic phenomena that usually mutate and develop (Rusbult \& Van Lange, 2003). 
Values are conceptions, explicit or implicit, typical of individual or group characteristics, of desires, which influence the choice of available modes, means, and ends of actions (Kluckhohn, 1951). Considering values is part of attitude with special emphasis on important concepts (Levy \& Guttman, 1976). According Rokeach (1973) the value as "is faith that a certain mode of behavior or existence is personally or socially better". In other words, values are internalized standards for one's own and others' behavior. Values as giving meaning to action. Values are standards replacing general evaluatives and relatively abstract defining desired goals and ways to achieve them (Olson \& Zanna, 1993). According Bisman (2004) values as basic principles and opinions that direct one's beliefs, attitudes, and behaviors. These values can influence beliefs about money, social interaction, the importance of work, and other aspects of social life and work environment. Value as a transsituational desired goal that serves as a principle in the life of a person or other social entity (Schwartz, 1992).

Many concepts and definitions of values, it continues to develop and emerge the term work value. Work-related values refer to the goals or rewards people seek through their work, and they are expressions of human values that are more common in the context of the work environment (Schwartz, 1999). Where Schwartz (1999) divides the value of work into four: (1) Intrinsic values related to personal, growth, autonomy, and creativity; (2) Extrinsic values by getting capital and having a feeling of security towards work; (3) Social values related to interaction with members of the organization and contributions to society; (4) The Value of Power relates to prestige, power, and influence. Whereas Zhao (1984) divides the value of work into four types: preferences, social interests, convenience of prestige, and economy.

Specifically looking at social values, where values are often associated with altruism. Social value or often called the work value of Altruism because of social norms related to giving priority to the interests of others and a sense of justice (Lerner \& Simmons, 1966; Simmons \& Lerner, 1968). Altruism known as self-sacrifice behavior benefits others, has attracted various scientific disciplines such as philosophy, psychology, economics and biology and have been investigated with various approaches (C. Batson, 1991). True altruism is defined as voluntary, intentional behavior that is motivated for the benefit of others who are not motivated by expectations of external appreciation or avoidance of punishment or hostility stimuli (C. D. Batson \& Powell, 2003; Chou, 1996; Miller, Birkholt, Scott, \& Stage, 1995). Perspective taking (Underwood \& Moore, 1982), empathy, guilt, and other emotions (C. Batson, 1991; Eisenberg, 2000).

Altruistic behavior is influenced by the intensity of moral (personal) obligations felt by individuals to take special assistance measures. the activation of internal norms that more specifically intervenes between awareness of one's needs and altruistic behavior (Schwartz, 1977). Altruistic values are actions that are carried out in accordance with individual moods and are an extension of personality. In this sense, it is suggested that a person's personality traits influence his altruistic behavior (Argan \& Argan, 2017; Nguyen, Lobo, \& Greenland, 2017). Altruistic value as a personal resource, is the main source of the formation of one's motivation to do voluntary activities (Bekkers, 2005; Kang et al., 2011; Musick \& Wilson, 2007). While other studies identify social support, especially those from family and close people, as a factor of the environment which has a strong influence in encouraging the emergence of voluntary behavior (Gibelman \& Sweifach, 2008).

The organizational context not only impacts individual personal experiences but also changes the way people interact with each other (Schaerer, Lee, Galinsky, \& Thau, 2018). Interactions and relationships, including power-dependency relationships, are dynamic phenomena that change and develop over time (Rusbult \& Van Lange, 2003). Research Axelrod (1984) mentions that people hope to interact with others in the future can fundamentally change the interpersonal dynamics of interactions and the effects of power on personal and collective outcomes.

Based on the description of social action theory, symbolic interaction theory, obedience theory, and the value theory above, as well as support from previous research studies, the new concept is described as follows: 


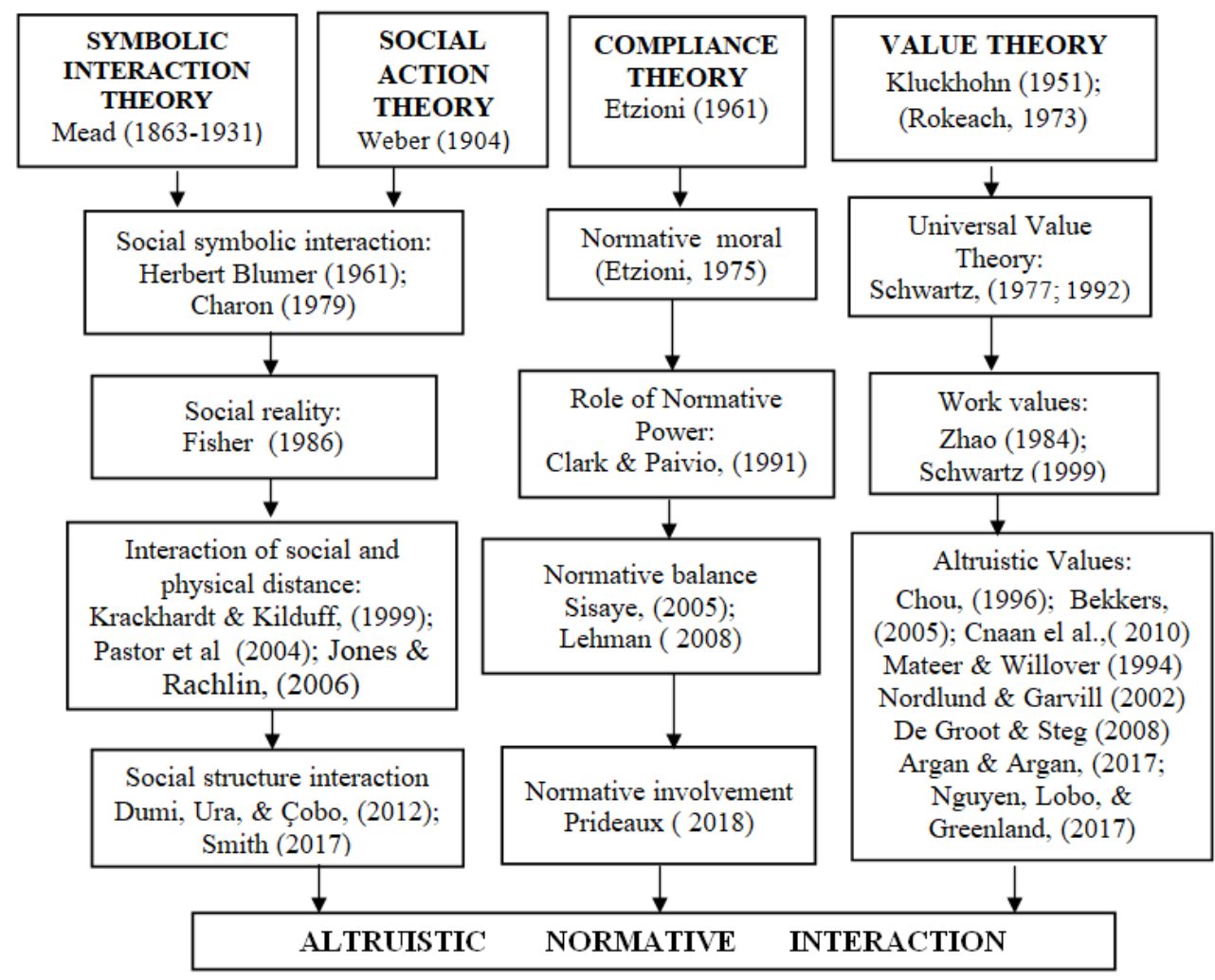

Figure 1 - Rationale for the concept of altruistic normative interaction

Thus the above description will bring up new naming as a new concept in research that is Altruistic Normative Interaction. The concept of altruistic normative interaction is defined as Relationships that take place verbally in an interpersonal order that is carried out reciprocally and continuously in organizations with moral involvement in a positive value orientation that puts social interests and welfare of others first.

To understand the phenomena of society, according Blumer (1954) a researcher must make direct or participatory observations, namely (1) exploration to the level of understanding that produces sensitivizing concepts; (2) conduct an inspection, must examine the data by displaying empirical evidence. A systematic investigation that provides information to solve managerial problems (Cooper, 2006). From the review, it is found that the altruistic normative interaction consists of indicators developed from several researchers as in the following table.

Table 1 - Synthesis of altruistic Normative Interaction Indicators

\begin{tabular}{|c|c|c|c|}
\hline Interaction & Normative & Altruistic Values & Altruistic Normative Interaction \\
\hline $\begin{array}{l}\text { intensive interaction of a cross } \\
\text { function, (Dumi, Ura, \& Çobo, } \\
\text { 2012) }\end{array}$ & $\begin{array}{c}\text { Listening and sharing } \\
\text { feelings, (Coopman 2001) }\end{array}$ & $\begin{array}{l}\text { Value of Equality for all } \\
\text { (De Groot \& Steg } \\
\text { 2008) }\end{array}$ & $\begin{array}{c}\text { Intensive interaction is carried } \\
\text { out equally in all fields }\end{array}$ \\
\hline $\begin{array}{l}\text { Intensive interaction of a cross } \\
\text { function, (Dumi, Ura, \& Çobo, } \\
\text { 2012) }\end{array}$ & $\begin{array}{l}\text { love normative rules (Etzioni, } \\
1975)\end{array}$ & $\begin{array}{c}\text { Cheerful value for all, } \\
\text { (Mateer \& Willover } \\
(1994)\end{array}$ & $\begin{array}{l}\text { Pleasant interaction relationship } \\
\text { free from conflict / personal } \\
\text { interests }\end{array}$ \\
\hline $\begin{array}{c}\text { Social interaction } \\
\text { interdependence (Schaerer, et } \\
\text { al 2018) }\end{array}$ & $\begin{array}{l}\text { team involvement improves } \\
\text { performance (Coopman 2001) }\end{array}$ & $\begin{array}{l}\text { Value Social justice } \\
\text { treats the weak (De } \\
\text { Groot \& Steg 2008) }\end{array}$ & $\begin{array}{c}\text { Interaction helps pay attention to } \\
\text { weaknesses and provide } \\
\text { solutions }\end{array}$ \\
\hline $\begin{array}{c}\text { Social interaction } \\
\text { interdependence. (Schaerer, et } \\
\text { al 2018) }\end{array}$ & $\begin{array}{l}\text { normative social structure, } \\
\text { moral involvement (Prideaux, } \\
\text { 2018); Etzioni, 1975) }\end{array}$ & $\begin{array}{l}\text { Useful: work for the } \\
\text { welfare of others } \\
\text { De Groot \& Steg } \\
(2008)\end{array}$ & $\begin{array}{l}\text { Give each other attention to } \\
\text { social conditions and welfare of } \\
\text { life }\end{array}$ \\
\hline $\begin{array}{l}\text { Interaction must be considered } \\
\text { (Bass \& Stogdill, 1990) }\end{array}$ & $\begin{array}{c}\text { rule-makers, normative } \\
\text { compliance. (Amitai Etzioni, } \\
\text { 1975) (Lehman, 2008) }\end{array}$ & $\begin{array}{l}\text { Value of protection } \\
\text { (Nordlund \& Garvill } \\
(2002)\end{array}$ & $\begin{array}{l}\text { Remind each other to carry out } \\
\text { company work procedures in } \\
\text { accordance with regulations. }\end{array}$ \\
\hline $\begin{array}{c}\text { Social interaction } \\
\text { interdependence (Schaerer, et } \\
\text { al 2018) }\end{array}$ & $\begin{array}{l}\text { Democracy of the team in } \\
\text { decision making (Coopman, } \\
\text { 2001) }\end{array}$ & $\begin{array}{l}\text { Peaceful world: conflict } \\
\text { free (De Groot \& Steg, } \\
\text { 2008) }\end{array}$ & $\begin{array}{l}\text { Interaction creates a conflict-free } \\
\text { workplace environment for team } \\
\text { performance }\end{array}$ \\
\hline
\end{tabular}




\section{CONCLUSION}

Humans are social creatures that interact in their organizations / environments. Humans cannot live alone and care for one another. Humans live towards a goal of prosperity and happiness. It takes togetherness between individuals with individuals, individuals and groups to establish reciprocal (interaction) and continuous relationships in groups that care about social values and put the welfare of members ahead of themselves. Altruistic normative interactions are expected to be behaviors that can be applied now and in the future.

\section{REFERENCES}

1. Ahmadi, D. (2008). Interaksi Simbolik: Suatu Pengantar. Mediator: Jurnal Komunikasi, 9(2), 301-316.

2. Argan, M. T., \& Argan, M. (2017). Do Altruistic Values of An Individual Reflect Personality Traits. International Journal of Recent Advances in Organizational Behaviour and Decision Sciences (IJRAOB) An Online International Research Journal, 3(1), 858-871.

3. Axelrod, R. (1984). The evolution of cooperation Basic Books. New York.

4. Bass, B. M., \& Stogdill, R. M. (1990). Bass \& Stogdill's handbook of leadership: Theory, research, and managerial applications: Simon and Schuster.

5. Batson, C. (1991). The altruism question: Toward a social psychological answer (p. 80). New Hillsdale, NY: Erlbaum.

6. Batson, C. D., \& Powell, A. A. (2003). Altruism and prosocial behavior. Handbook of psychology, 463-484.

7. Baum, I. J. (2002). Companion to organizations. Malden, MA: Blackwell Publishing.

8. Bekkers, R. (2005). Charity begins at home: How socialization experiences influence giving and volunteering.

9. Bisman, C. (2004). Social work values: The moral core of the profession. The British Journal of Social Work, 34(1), 109-123.

10. Blumer, H. (1954). What is wrong with social theory? American sociological review, 19(1), 3-10.

11. Charon, J. M., \& Interactionism, S. (1979). An introduction, an interpretation, an integration: New Jersey: Prentice Hall, Englewood Cliffs.

12. Chou, K.-L. (1996). The rushton, chrisjohn and fekken self-report altruism scale: a chinese translation. Personality and Individual Differences, 21(2), 297-298.

13. Clark, J. M., \& Paivio, A. (1991). Dual coding theory and education. Educational psychology review, 3(3), 149-210.

14. Cooper, D. R. a. P. S. S. (2006). Business Research Methods: New York, NY: Irwin/McGraw-Hill.

15. Coopman, S. J. (2001). Democracy, performance, and outcomes in interdisciplinary health care teams. The Journal of Business Communication (1973), 38(3), 261-284.

16. Dumi, A. D. A. R., Ura, P. D. E., \& Çobo, M. E. (2012). Management Concepts and Theories, the Strategic Development Levels on Transfer Organizational Work in the Poor Countries. Rome, Italy 2012, 181.

17. Eisenberg, N. (2000). Empathy and sympathy. In M. Lewis \& J. M. Haviland (Eds.),. Handbook of emotions (2nd ed., pp. 677-691). New York: Guilford.

18. Etzioni, A. (1961). Complex organizations: On power, involvement, and their correlates: New York: Free Press.

19. Etzioni, A. (1975). Comparative analysis of complex organizations, rev: Simon and Schuster.

20. Flynn, F. J., Gruenfeld, D., Molm, L. D., \& Polzer, J. T. (2011). Social psychological perspectives on power in organizations. Administrative Science Quarterly, 56(4), 495500.

21. Gibelman, M., \& Sweifach, J. (2008). Acting on our values: Do social workers volunteer? Social Work, 53(1), 53-64. 
22. Hamlin, R. G. (2005). Toward universalistic models of managerial leader effectiveness: A comparative study of recent British and American derived models of leadership. Human Resource Development International, 8(1), 5-25.

23. Kang, C., Handy, F., Hustinx, L., Cnaan, R., Brudney, J. L., Haski-Leventhal, D., (2011). What gives? Cross-national differences in students' giving behavior. The Social Science Journal, 48(2), 283-294.

24. Katz, D., \& Kahn, R. L. (1978). The social psychology of organizations (Vol. 2): Wiley New York.

25. Kelley, H. H. (1984). The theoretical description of interdependence by means of transition lists. Journal of personality and social psychology, 47(5), 956.

26. Kelley, H. H., Holmes, J. G., Kerr, N. L., Reis, H. T., Rusbult, C. E., \& Van Lange, P. A. (2003). An atlas of interpersonal situations: Cambridge University Press.

27. Kluckhohn, C. (1951). Values and value-orientations in the theory of action: An exploration in definition and classification.

28. Lehman, E. W. (2008). 'The Moral Dimension'and'The Action Frame of Reference': lessons for sociologists. Socio-Economic Review, 6(1).

29. Lerner, M. J., \& Simmons, C. H. (1966). Observer's reaction to the" innocent victim": Compassion or rejection? Journal of personality and social psychology, 4(2), 203.

30. Levy, S., \& Guttman, L. (1976). Values and Attitudes of Israel High School Youth: Second Research Project; Translation of Introduction and Summary: Israel Institute of Applied Social Research.

31. Miller, K., Birkholt, M., Scott, C., \& Stage, C. (1995). Empathy and burnout in human service work: An extension of a communication model. Communication Research, 22(2), 123-147.

32. Miron, E., Erez, M., \& Naveh, E. (2004). Do personal characteristics and cultural values that promote innovation, quality, and efficiency compete or complement each other? Journal of organizational behavior, 25(2), 175-199.

33. Musick, M. A., \& Wilson, J. (2007). Volunteers: A social profile: Indiana University Press.

34. Nguyen, T. N., Lobo, A., \& Greenland, S. (2017). The influence of Vietnamese consumers' altruistic values on their purchase of energy efficient appliances. Asia Pacific Journal of Marketing and Logistics, 29(4), 759-777.

35. Olson, J. M., \& Zanna, M. P. (1993). Attitudes and attitude change. Annual review of psychology, 44(1), 117-154.

36. Prideaux, S. (2018). From organisational theory to the Third Way: Continuities and contradictions underpinning Amitai Etzioni's communitarian influence on New Labour The Third Way and beyond: Manchester University Press.

37. Raelin, J. A., \& Cooledge, A. S. (1995). From generic to organic competencies. People and Strategy, 18(3), 24.

38. Ritzer, G., \& Stepnisky, J. (2017). Modern sociological theory: Sage publications.

39. Rokeach, M. (1973). The nature of human values: Free press.

40. Rosenberg, M. M. (2016). The conceptual articulation of the reality of life: Max Weber's theoretical constitution of sociological ideal types. Journal of Classical Sociology, 16(1), 84-101.

41. Rusbult, C. E., \& Van Lange, P. A. (2003). Interdependence, interaction, and relationships. Annual review of psychology, 54(1), 351-375.

42. Schaerer, M., Lee, A. J., Galinsky, A. D., \& Thau, S. (2018). Contextualizing social power research within organizational behavior. The self at work: Fundamental theory and research, 194-221.

43. Schwartz, S. H. (1977). Normative influences on altruism Advances in experimental social psychology (Vol. 10, pp. 221-279): Elsevier.

44. Schwartz, S. H. (1992). Universals in the content and structure of values: Theoretical advances and empirical tests in 20 countries Advances in experimental social psychology (Vol. 25, pp. 1-65): Elsevier.

45. Schwartz, S. H. (1999). A theory of cultural values and some implications for work. Applied psychology, 48(1), 23-47. 
46. Shao, L., \& Webber, S. (2006). A cross-cultural test of the 'five-factor model of personality and transformational leadership'. Journal of Business research, 59(8), 936944.

47. Simmons, C. H., \& Lerner, M. J. (1968). Altruism as a search for justice. Journal of personality and social psychology, 9(3), 216.

48. Sisaye, S. (2005). Teams and management control systems: a synthesis of three organizational development approaches. Leadership \& Organization Development Journal, 26(3), 172-185.

49. Smith, P. K., \& Hofmann, W. (2016). Power in everyday life. Proceedings of the National Academy of Sciences, 113(36), 10043-10048.

50. Smith, R. B. (2017). Symbolic Interaction Theory. The Encyclopedia of Juvenile Delinquency and Justice, 1-4.

51. Underwood, B., \& Moore, B. (1982). Perspective-taking and altruism. Psychological bulletin, 91(1), 143.

52. Veeger, K. (1985). Realitas Sosial: refleksi filsafat sosial atas hubungan individumasyarakat dalam cakrawala sejarah sosiologi: Penerbit PT Gramedia Pustaka Utama.

53. Zhao, X. S. (1984). Research on guidance of youth work values (in Chinese). Youth research, 3, 24. Youth research, 3, 24. 